Missio Ecclesiae, 5(2), Oktober 2016, 169-189

\title{
BERSAKSI TENTANG KRISTUS SEBAGAI GAYA HIDUP PEMUDA GEREJA MASA KINI
}

\author{
Natalia Debora Pantas
}

\section{PENDAHULUAN}

Gereja sudah berada di dalam rencana kekal Tuhan Allah. Oleh karena itu, Gereja bukanlah gedung. Gereja juga bukan organisasi atau administrasi. Gereja bukan upacara atau tradisi. Gereja adalah tubuh Kristus. Gereja adalah umat Tuhan. Seluruh umat Tuhan disebut sebagai bait Allah yang hidup di dalam dunia. Gereja adalah kaum pilihan, hasil tebusan Allah. Gereja adalah bangsa yang kudus dan Imamat yang rajani. Gereja adalah garam dan terang dunia. Gereja adalah saksi Kristus di dunia, di tengah orang berdosa. ${ }^{1}$ Menurut Luther gereja sebagai persekutuan spiritual dari orang-orang yang percaya kepada Kristus. Gereja dipanggil untuk mendemonstrasikan kebenaran dan kedamaian dari Kerajaan Allah yang akan mempengaruhi misinya yaitu penginjilan dan pelayanan sosial di dunia. $^{2}$

Sehubungan dengan ini Stephen Tong mengemukakan bahwa gereja adalah orang yang dipilih sesuai dengan kehendak Allah Bapa. Orang-orang itu dikuduskan oleh Roh Kudus, agar bisa taat kepada Kristus. Dan orang tersebut dibersihkan oleh darah Kristus. Ketiga hal ini harus menjadi pengalaman umat pilihan Allah atau gereja yang sesungguhnya. ${ }^{3}$ Seperti halnya yang dijelaskan oleh Makmur Halim, apabila orang berdosa menerima Kristus sebagai Tuhan dan Juruselamat secara pribadi, maka ia mengalami anugerah keselamatan itu dan menjadi anak-anak Allah. Mereka juga dipanggil untuk hidup bagi Allah dan sesamanya. Mereka harus menjadi saksi-saksi Kristus untuk membawa berita keselamatan itu bagi orang lain. ${ }^{4}$ Bersaksi atau menjadi saksi Tuhan bukan hanya tugas dan panggilan hamba Tuhan yang menempuh pendidikan Teologia atau majelis gereja, tetapi itu juga panggilan semua orang percaya atau gereja Tuhan. Orang percaya sebagai saksi dari kebaikan dan kasih Allah kepada manusia. ${ }^{5}$ Termasuk di dalamnya adalah para pemuda atau kaum muda gereja.

${ }^{1}$ Stephen Tong, Kerajaan Allah, Gereja dan Pelayanan, (Surabaya: Penerbit Momentum, 2007), 33

${ }^{2}$ Stevri I. Lumintang, Misiologia Kontemporer, (Batu: Departemen Literatur PPII, 2006), 145

${ }^{3}$ Stephen Tong, Kerajaan Allah, Gereja dan Pelayanan..., 35

${ }^{4}$ Makmur Halim, Model-model Penginjilan Yesus, (Malang: Penerbit Gandum Mas, 2003), 31

${ }^{5}$ George Verwer, Melangkah Keluar dari Kenyamanan Dunia, (Jakarta: Yayasan Obor Mitra, 2001), 26-27 
Dalam buletin PILLAR edisi Januari 2007, generasi muda digambarkan sebagai seorang pelari estafet yang sedang menjulurkan tangannya ke belakang sambil melebarkan telapak tangannya dan menunggu, siap menerima tongkat pendek yang sebentar lagi akan sampai di tangannya. Kelangsungan sebuah gerakan hanya dapat terjadi ketika tongkat estafet berhasil disambut dan diteruskan oleh kaum mudanya.

Dalam perkembangan jaman yang semakin cepat di era globalisasi saat ini membuat anak-anak muda berusaha tampil dengan mengikuti tren yang sedang berkembang. Kecenderungan anak-anak muda adalah berusaha untuk bisa mendapat pengakuan dari lingkungan sekitarnya. Mereka berusaha agar dapat diterima dalam lingkungan pergaulannya yaitu dengan cara mengikuti tren yang ada saat ini. Jika mereka tidak mengikuti tren yang sedang berkembang, maka mereka akan dianggap ketinggalan jaman dan kurang pergaulan.

Banyak hal yang bisa dianggap tren bagi anak muda, mulai dari cara berpakaian, cara berbicara, cara berdandan/bergaya, gaya hidup, tempat jalan-jalan, tempat hiburan, tempat berbelanja, barang-barang mewah, musik, film, teknologi gadget, internet, bahkan sampai kepada kebiasaan buruk yaitu merokok hingga kepada dunia gemerlap (kehidupan malam). Sebagai anak muda yang mengenal Tuhan, tentunya harus dengan cermat mengikuti tren-tren yang ada. Anak-anak muda harus dapat memilih tren atau gaya hidup mana yang baik dan mana yang tidak baik bagi mereka, agar tetap berjalan dalam kehendak Tuhan dan tidak menyimpang dari jalan-Nya. ${ }^{6}$ Tentunya Gereja memiliki peranan penting dalam mengarahkan dan mempersiapkan pemuda dalam menghadapi tren dunia yang dapat merusak gaya hidup kekristenan. Mandat dan tugas gereja adalah agar pemuda mampu menjadi saksi di dunia. ${ }^{7}$ Hal bersaksi belum dilakukan oleh semua pemuda gereja. Tentunya dalam hal ini kerinduan dan komitmen untuk bersaksi tentang Kristus harus dimiliki oleh anak muda gereja. Berdasarkan beberapa persoalan ini, maka mendorong penulis untuk mengkaji lebih jauh berkenaan dengan "Bersaksi tentang Kristus sebagai Gaya Hidup Pemuda Gereja Masa Kini'.

\section{BERSAKSI}

Berikut ini penulis memaparkan beberapa istilah yang berkaitan dengan pembahasan selanjutnya guna memahami tulisan ini. Beberapa pengertian istilah yang digunakan adalah sebagai berikut:

\section{Pengertian kata Bersaksi secara umum}

Kata bersaksi merupakan kata kerja. Dalam Kamus Besar Bahasa Indonesia bersaksi berarti 1. Ada saksinya; mempunyai (memakai) saksi; 2. Menyatakan

\footnotetext{
${ }^{6}$ http://www.pelitahidup.com/2009/08/10/berani-tampil-beda/\#.Ut8_nN3QOIU

http://mindawatiperanginangin.blogspot.com/2008/06/gereja-dan-tantangan-pemuda-dalam.html,
} 
(mengakui) dengan sesungguhnya. Sedangkan kata bendanya adalah saksi. Masih dalam Kamus Besar Bahasa Indonesia, saksi artinya 1. Orang yang melihat atau mengetahui sendiri suatu peristiwa (kejadian). 2. Orang yang diminta hadir pada suatu peristiwa yang dianggap mengetahui kejadian tersebut agar pada suatu ketika, apabila diperlukan, dapat memberikan keterangan yang membenarkan bahwa peristiwa itu sungguh-sungguh terjadi. ${ }^{8}$ Dalam Kamus Bahasa Inggris witness, artinya saksi, bukti, tanda, menjadi saksi, menyaksikan, membuktikan, menjadi bukti. ${ }^{9}$ Selain itu digunakan kata testimony yang artinya kesaksian, penyaksian, bukti, pernyataan terbuka tentang agama atau kepercayaan seseorang.

\section{Pengertian kata Bersaksi Dalam Perjanjian Lama}

Dalam Perjanjian Lama ada beberapa istilah yang dipergunakan sehubungan dengan kata bersaksi. Beberapa di antaranya adalah ud, ed, edah, edut dan anah.

\section{Kata Ud}

Kata Ibrani $u d$ diterjemahkan dalam beberapa kata yaitu to testify, to witness, to give testimony yang artinya adalah memberikan kesaksian. Arti utama dari kata kerja ini adalah dalam terjemahan bahasa Inggris to repeat (berulang-ulang) atau do again (mengerjakan kembali). Bersaksi memiliki arti mengulangi atau menceritakan ulang pernyataan mengenai apa yang terjadi.Istilah yang digunakan dalam bahasa Inggris adalah to witness. Hal ini memberikan kesan peringatan. Seringkali Allah memperingatkan orang melalui nabi-nabi-Nya. ${ }^{11}$ Istilah ini terdapat dalam Yeremia 42:19 yang berbunyi: "TUHAN telah berfirman kepadamu, hai sisa Yehuda: Janganlah pergi ke Mesir! Camkanlah sungguh-sungguh, bahwa aku memperingatkan kamu pada hari ini!. Dan juga terdapat dalam Amos 3:13 yang berbunyi: "Dengarkanlah, dan peringatkanlah kaum keturunan Yakub, demikianlah Firman Tuhan ALLAH, Allah semesta alam...". Jadi, dapat disimpulkan ud berarti memberikan kesaksian secara berulang-ulang sebagai suatu peringatan.

\section{Kata 'ed}

Menurut hukum dalam Perjanjian Lama, seorang saksi ('ed) adalah seseorang yang dari dekat atau tangan pertama yang mengetahui dan melaporkan apa yang ia lihat dan dengar. ${ }^{12}$ Istilah ini digunakan dalam Imamat 5:1, yang berbunyi: Apabila seorang

\footnotetext{
8 , Kamus Besar Bahasa Indonesia, (Jakarta: Balai Pustaka, 2001), 981

${ }^{9}$ Hornby, dkk, Kamus Inggris Indonesia, (Jakarta: PT Pustaka Ilmu, 1984), 365

${ }^{10}$ Ibid..., 333

${ }^{11}$ Lawrence O Richards, Expository Dictionry of Bible Words, (Grand Rapids Michigan: Regency Reference Library, 1985), 594

${ }^{12}$ Ibid.
} 
berbuat dosa, yakni jika ia mendengar seorang mengutuki, dan ia dapat naik saksi karena ia melihat atau mengetahuinya, tetapi ia tidak mau memberi keterangan, maka ia harus menanggung kesalahannya sendiri. Sepuluh Hukum Taurat berbicara keras melawan atau menentang saksi yang tidak benar (Kel.20:16; U1.5:20). Dan seseorang yang mengadukan atau menuntut orang lain untuk menghukum dengan hukuman atas suatu kejahatan atau kesalahan yang mana ia ternyata merupakan terdakwa atau tertuduh dari yang diberitakannya (Ul.19:15-21). Saksi-saksi juga dipanggil jika ada transaksi yang bersifat perdagangan yang harus diselesaikan (Yer.32:6-15). ${ }^{1}$

Jadi, dapat disimpulkan 'ed lebih menunjuk kepada seorang saksi sebagai pihak pertama yang mengetahui suatu peristiwa dan dapat melaporkan hal tersebut.

\section{Kata edah, edut}

Kata ini dalam bahasa Inggris diterjemahkan testimony. Istilah edah dan edut sering menunjuk kepada Allah yang memberi kesaksian kepada manusia. Kesaksian ini dalam pengertian "hukum" seperti dalam bagian Mazmur pasal 19 dan 119. Bahtera Nuh, Tabut Perjanjian dan Sepuluh Hukum Taurat sering menggambarkan seperti kesaksian Allah. Penegasan dan penguatan oleh Tuhan akan janji-Nya dan tujuan-Nya. ${ }^{14}$ Jadi, kesaksian berdasarkan kata edah dan edut lebih menunjuk kepada Tuhan Allah sebagai yang memberi kesaksian

\section{Kata anah}

Istilah anah merupakan kata kerja yang artinya memberi jawab atau respon. Dalam bahasa Inggris diterjemahkan to testify. ${ }^{15}$ Kata ini dipakai dalam Keluaran 20:16 yang berbunyi: Jangan mengucapkan saksi dusta tentang sesamamu.

Pokok yang mendasari konsep, kemudian memberi kesan pernyataan yang kuat oleh seseorang dengan tangan pertama yang memiliki pengetahuan dari apa yang ia ketahui. Kesaksian mungkin di sebuah tempat pengadilan, mungkin di dalam hal transaksi bisnis, atau barangkali melayani seperti sebuah peringatan. Hal ini juga dapat menjadi kata-kata yang kuat atau pernyataan simbolis dari kebenaran yang dipercaya. Perjanjian lama memberikan peringatan melawan kesaksian yang tidak benar dan Allah sendiri memelihara contoh/teladan dari kebenaran firman-Nya. ${ }^{16}$

Jadi, kata anah menunjuk pada suatu kesaksian yang benar sebagai suatu pernyataan yang kuat dari kebenaran yang dapat dipercayai.

\footnotetext{
${ }^{13}$ Lawrence O Richards, Expository Dictionry ..., 595

${ }^{14}$ Ibid.

${ }^{15}$ Ibid.

${ }^{16}$ Ibid.
} 


\section{Missio Ecclesiae, 5(2), Oktober 2016, 169-189}

\section{Pengertian Kata Bersaksi Dalam Perjanjian Baru}

Berkenaan dengan istilah bersaksi dari kata benda martyria memberikan arti dan menyatakan aktiv. Martyr, martyria menunjukkan penegasan dari suatu fakta atau peristiwa/kejadian yang terbukti kebenarannya. Berhubungan dengan hal ini mencoba untuk menggambarkan, memperhatikan kembali, mengingat pada suatu kejadian atau pengalaman. Hal ini tidak dapat diabaikan atau dilupakan pada masa sekarang. Dengan demikian memberikan pengertian akan maksud dari pernyataan yang tepat dan merupakan isi dari pengalaman serta menjadi fakta-fakta atau bukti dari suatu kesaksian.

Masih dalam kaitannya dengan bersaksi dari kata kerja martyreo. Dalam bahasa Inggris digunakan istilah "To bear witness" (memberikan kesaksian), "to be a witness for something" (menjadi seorang saksi terhadap sesuatu), dan juga untuk menegaskan sesuatu kepada seseorang dengan mempergunakan suatu fakta atau bukti. Tujuannya adalah untuk memberikan kesaksian sesuatu yang adalah keadaan yang sebenarnya. Istilah lain yang dipakai adalah martyromai artinya memanggil seseorang sebagai saksi. Pada bagian ini berkaitan dengan kata benda martyrion untuk fakta-fakta atau bukti dengan membandingkannya pada perbuatan. Orang yang diperintahkan untuk maju seperti saksi-saksi memberikan penegasan sebuah tuntutan atau untuk menjelaskan beberapa fakta. Berkaitan dengan istilah martyr atau martir berarti saksi atau orang yang mati syahid karena kesaksiannya. ${ }^{17}$

Dari kata martyr juga bisa menjadi kata Symamartyreo artinya menjadi seorang saksi dari seseorang. Istilah lainnya katamartyreo: memberikan arti atau memberikan fakta/bukti melawan atau menentang seseorang. Kata lainnya diamartyromai artinya dipanggil untuk menjadi saksi, untuk menyatakan, untuk memperlihatkan, membuktikan dan tetap mempunyai dorongan bersaksi secara kuat. ${ }^{18}$

Menurut Ensiklopedi Alkitab Masa Kini kesaksian adalah tanggung jawab berat, teristimewa dalam kasus yang diancam dengan hukuman mati. Apabila terbukti tertuduh bersalah, maka para saksi memimpin regu pelaksana hukuman mati itu (Kis.7:58). Dalam Perjanjian Baru, para rasul adalah saksi-saksi utama tentang hidup dan kebangkitan Kristus (Yoh.21:24; Kis.1:22; 2 Ptr 1:6). Dalam gereja purba, kata Yunani martus menjadi terbatas, terutama untuk menyebut mereka yang setia kepada imannya kendati sampai mati sekalipun. Penggunaan kata ini dalam bahasa Indonesia dikenal dengan martir. Dalam dunia Kristen modern, "kesaksian" berarti cerita tentang apa yang dikerjakan Kristus atas hidup seseorang, yang menjadi pengalaman pribadi orang itu. ${ }^{19}$

Berkenaan dengan pengertian bersaksi, Will Metzger memaparkan bahwa hal ini berkaitan dengan kebenaran-kebenaran pokok yang harus disaksikan (Luk.24:48). Latar belakang dari kata saksi adalah sidang pengadilan. Bersaksi artinya memberikan kesaksian bahwa Kristus adalah pribadi seperti yang dikatakan-Nya. Kesaksian seperti

${ }^{17}$ Henk Ten Napel, Kamus Teologia Inggris-Indonesia, (Jakarta: BPK Gunung Mulia, 1989), 107

18 Ibid.

${ }^{19}$ J.D. Douglas, Ensiklopedi Alkitab Masa Kini Jilid 2 M-Z, (Jakarta: Yayasan Bina Kasih/OMF, 1995), 340 
itu adalah cara untuk mencapai tujuan dengan memberikan kesaksian dari seorang saksi mata tentang kebenaran (1 Yoh. $1: 1-3) .^{20}$

\section{Pribadi Yang bersaksi}

Saksi adalah seorang yang mempunyai pengalaman pribadi atau pengetahuan langsung mengenai sesuatu hal (Yes.43:9-12; 44:8). Orang-orang Kristen disuruh menjadi saksi tentang apa yang mereka ketahui dan alami mengenai Kristus (Kis.1:8). Oleh karena sekian banyak saksi-saksi Kristus yang mula-mula itu setia sampai mati (Kis.22:20; Why.2:13; 17:6), maka kata dalam bahasa Yunani yang berarti saksi (martus) kini sudah menjadi kata dalam bahasa Inggris yang berarti syahid (martyr). ${ }^{21}$

Mengenai saksi-saksi Park menjelaskan bahwa hanya saksi-saksi yang diangkat sebagai peletak dasar gereja, yakni rasul-rasul yang dipercayakan melihat karya Kristus (kematian dan kebangkitan Yesus Kristus) dengan matanya sendiri (1 Kor. 9:1). Sebab, agama Kristen adalah agama yang memberitakan karya Kristus, bukan agama yang mengajarkan gagasan-gagasan yang ideal, maka rasul-rasul sebagai pemberita Injil pertama, harus menyaksikan dengan matanya sendiri; tetapi orang-orang lain ditetapkan untuk percaya dengan hanya mendengar dari rasul-rasul. Iman yang sama dengan iman yang dimiliki rasul-rasul akan diberikan kepada manusia melalui Firman Allah (Alkitab) dan Roh Kudus. ${ }^{22}$

Metzger mengemukakan mengenai latar belakang dari kata saksi adalah sidang pengadilan. Bersaksi artinya memberikan kesaksian bahwa Kristus adalah Pribadi seperti yang dikatakanNya. Kesaksian seperti itu adalah cara untuk mencapai tujuan memberikan kesaksian dari seorang saksi mata tentang kebenaran (1 Yoh. 1: 1- 3). ${ }^{23}$

Berkaitan dengan menjadi saksi, Wiersbe menjelaskan mengenai Stefanus, sang saksi (Kis. 6:8- 15) bahwa Stefanus adalah seorang yang penuh Roh Kudus dan tidak membatasi pelayanannya hanya pada pelayan meja saja. Allah memakai Stefanus menjadi saksi bagi para pemimpin Israel. Kesaksian Stefanus yang penuh kuasa itu menjadi klimaks dari kesaksian gereja kepada orang Yahudi. Sesudah itu berita Injil tersebar kepada orang-orang Samaria dan kemudian kepada orang-orang non-Yahudi. ${ }^{24}$

Tuhan Yesus telah meminta orang percaya menjadi saksi-Nya. ${ }^{25}$ Seorang saksi bagi Kristus adalah orang yang mengenal Dia dan yang mempunyai kerinduan untuk memperkenalkan Dia kepada orang lain. ${ }^{26}$ Rinker mengemukakan bahwa saudara harus mengenal seseorang sebelum saudara memperkenalkan dia kepada orang lain. Yesus

${ }^{20}$ Will Metzger, Tell The Truth, (Surabaya: Penerbit Momentum, 2005), 16

21 W.N. Mcelrath-Billy Mathias, Ensiklopedia Alkitab Praktis, (Bandung: Lembaga Literatur Baptis, 1986), 125

${ }^{22}$ Park, Yun Sun, Tafsiran Alkitab Kisah Para Rasul, (Batu: Departemen Literatur YPPII, 2001), 174

${ }^{23}$ Will Metzger, Beritakan Kebenaran..., 16

${ }^{24}$ Warren W. W. Wiersbe, Dinamis Di Dalam Kristus...,, 88

${ }^{25}$ Rosalind Rinker, Bersaksi Dengan Tenang Hati, (Surabaya: YAKIN, 1991), 23

${ }^{26}$ Ibid., 39 
berkata bahwa kita akan menjadi saksi-saksi yang penuh kuasa bagiNya, bila Roh Kudus turun atas kita (Kis. 1: 8). Dengan demikian Kristus menjadi nyata dalam hidup orang percaya. Orang percaya adalah saksi akan hal tersebut. Hidup orang percaya yang telah diubahkan menjadi saksi tentang kekuasaan Kristus. ${ }^{27}$

Jadi, pribadi yang bersaksi atau menjadi saksi adalah seorang yang telah percaya kepada Kristus. Seperti halnya para rasul yang mengalami langsung karya Kristus, seorang saksi juga mengalami hal itu di dalam dirinya. Ia memiliki pengalaman pribadi dengan Kristus melalui itu karya keselamatan Allah dinyatakan di dalam dirinya dan dia dapat memberitahukannya kepada orang lain.

\section{$\underline{\text { Isi Kesaksian }}$}

Kabar baik yang disampaikan dalam kesaksian adalah berbicara tentang Pribadi Kristus sendiri. Dialah Tuhan Yesus dan Juruselamat bagi setiap orang yang percaya kepada-Nya. Tentang nama Jesus dijelaskan dalam Expository Dictionary sebagai berikut: "The name Jesus is transliteration of the Greek form of the Hebrew name Joshua. The meaning of the Hebrew name is "Yahweh is salvation". The name was chosen by God and communicated to Joseph an Mary by angel". ${ }^{28}$ Anak itu akan diberi nama Yesus karena Ia akan menyelamatkan manusia dari dosa-doa (Mat.1: 21; Luk.1: 31). Sedangkan kata kurios ('tuan') digunakan pada masa Perjanjian Baru sebagai gelar kehormatan yang diberikan kepada seseorang yang lebih tinggi kedudukannya. Gelar itu juga digunakan sebagai sebutan untuk kaisar Roma. Tetapi gelar itu mempunyai arti khusus bagi orang-orang Yahudi karena sering digunakan dalam LXX sebagai terjemahan kata Ibrani Adonay, yang sering dipergunakan sebagai pengganti kata YHWH. $^{29}$

Sehubungan dengan ini Guthrie menjelaskan bahwa gelar Tuhan khususnya disukai oleh Lukas dalam menceritakan perbuatan-perbuatan dan pengajaran-pengajaran dari jemaat mula-mula. Gelar tersebut dipakai bagi Yesus secara langsung dan hampir selalu digunakan dengan sendirinya. Secara khusus dalam khotbah Petrus kepada Kornelius, sehubungan dengan Firman yang memberitakan damai sejahtera oleh Yesus Kristus, ia berkata "Dia adalah Tuhan dari semua orang" (Kis.10: 36). Inilah pandangan yang luar biasa mengenai ketuhanan Yesus, yang menyatakan bahwa Ia memiliki hak penuh kekuasaan pemerintahan sorgawi. Keterangan dari Kisah Para Rasul menunjukkan bahwa ketuhanan Kristus mempunyai dampak kualitas sebagai Allah. ${ }^{30}$

Hal yang serupa juga dikemukakan oleh Morris bahwa gelar yang paling sering dipakai Lukas untuk Yesus adalah Tuhan. Dicatat sebanyak 103 kali dalam Injilnya dan 107 kali dalam Kisah Para Rasul. Gelar ini memiliki bermacam-macam arti. Seperti gelar (The Lord) yang dipakai untuk pemilik dari segala sesuatu misalnya keledai (Luk.

\footnotetext{
${ }^{27}$ Ibid., 41

${ }^{28}$ Lawrence O. Richards, Expository Dictionary of Bible Words..., 360

${ }^{29}$ Donald Guthrie, Teologi Perjanjian Baru, (Jakarta: BPK Gunung Mulia, 1991), 327

${ }^{30}$ Ibid., 330-331
} 
19: 33) atau kebun anggur (Luk. 20: 13). Gelar itu sebagai bentuk sapaan yang sopan seperti seorang pelayan menyapa majikannya (Luk. 13: 8; 14: 22). Penggunaan gelar tersebut menjadi cara biasa untuk menyapa atau berbicara tentang seorang yang lebih mulia atau orang-orang yang memiliki kedudukan tinggi. ${ }^{31}$ Inilah inti dari kesaksian setiap orang percaya, yaitu memberitakan tentang Yesus Kristus adalah Tuhan dan juru selamat manusia.

\section{Cara bersaksi}

Berkenaan dengan hal ini Ray Comfort memaparkan tentang bagaimana ia memulai bersaksi:

Saudara dapat memulai percakapan dengan seseorang dengan membicarakan tentang cuaca, olahraga atau kejadian sehari-hari. Kemudian tanyalah kepada orang tersebut dimana ia tinggal atau apa pekerjaannya. Akan tetapi, berhatihatilah jangan sampai saudara terlibat jauh dalam percakapan sehingga saudara tidak dapat mengalihkan pembicaraan tersebut. Semakin lama saudara membicarakansuatu masalah, semakin sulit untuk beralih ke masalah rohani. Saya kira langkah terbaik selanjutnya adalah bertanya, "Apakah saudara memiliki latar belakang Kristen?" Kebanyakan orang berdosa menjawab, "saya pergi ke sekolah Minggu ketika saya masih kanak-kanak, namun ketika saya semakin besar, saya tidak lagi ke Sekolah Minggu". Apabila saudara tidak mendapat omongan yang tajam, seperti "saya tidak suka membicarakan agama dan politik, terima kasih!" saudara dapat menyimpulkan bahwa pendengar saudara mempunyai telinga yang terbuka. ${ }^{32}$

Orang percaya dipanggil untuk menjadi garam dunia. Roy Comfort mengemukakan bahwa: "Garam tidak akan ada gunanya jika hanya berada di tempatnya. Demikian juga dengan gereja, kelompok pemuda, kelompok wanita atau pria harus bersaksi". Kesempatan banyak, karena itu mintalah kepada Allah cara-cara yang kreatif untuk bersaksi dan memberitakan Injil kepada orang yang terhilang. ${ }^{33}$

Mark Simon dalam tulisannya mengemukakan bahwa Injil adalah kabar baik bahwa Yesus Kristus adalah Anak Allah yang telah bangkit sehingga dosa-dosa setiap orang yang percaya diampuni dan orang itu didamaikan dengan Allah. Tindakan orang Kristen yang penuh dengan keramahan dan kasih mengarahkan perhatian orang kepada Injil, tetapi selama berita Injil belum disampaikan secara jelas, tindakan tersebut belum bisa dikatakan sebagai penyampaian Injil secara lengkap. ${ }^{34}$

\footnotetext{
${ }^{31}$ Leon Morris, Teologi Perjanjian Baru, (Malang: Penerbit Gandum Mas, 1996), 230

${ }^{32}$ Ray Comfort, Misteri Neraka yang Kurang Diberitakan, (Malang:Yayasan Penerbit Gandum Mas, 1998), 99

${ }_{34}^{33}$ Ibid..., 103 Theologia Aletheia, 2014), 72 Jurnal Theologia Aletheia Vol.16 No.6 Maret 2014, (Lawang: Sekolah Tinggi
} 
Sehubungan dengan hal bersaksi, Will Metzger menjelaskan mengenai bersaksi dalam definisi yang sempit dan luas. Dalam definisi yang sempit, bersaksi dibatasi pada membicarakan fakta-fakta Injil kepada orang yang belum percaya. Sedangkan definisi luasnya adalah segala sesuatu yang kita perbuat sebagai orang Kristen di hadapan mata dunia. Kedua definisi ini belum memadai. Definisi pertama berkaitan dengan cara bersaksi hanya dibatasi pada perkataan orang Kristen; yang kedua memperluasnya menjadi suatu perilaku yang baik. Seharusnya, baik perkataan maupun perbuatan terjalin menjadi satu dan tak terpisahkan dalam bersaksi. ${ }^{35} \mathrm{Jadi}$, cara bersaksi bukan hanya melalui tindakan saja tetapi harus melalui perkataan. Keduanya dilakukan secara bersama-sama. Bersaksi bukan hanya memproklamasikan Injil tetapi juga hidup berpadanan dengan Injil Kristus.

\section{GAYA HIDUP PEMUDA KRISTEN}

Kehidupan masyarakat di zaman sekarang ini tentunya mengalami perkembangan yang pesat. Zaman masa kini yang disebut sebagai postmodern ini diikuti dengan kemajuan ilmu pengetahuan dan teknologi. Hal ini tentunya berdampak pada gaya hidup masyarakat saat ini apalagi bagi para pemuda secara khusus pemuda Kristen.

\section{Pengertian gava hidup}

Menurut Kamus Besar Bahasa Indonesia gaya hidup adalah pola tingkah laku sehari-hari segolongan manusia di masyarakat. ${ }^{36}$ Pengertian yang hampir sama yaitu gaya hidup merupakan pola kehidupan segolongan orang. ${ }^{37}$ Gaya hidup merupakan perilaku seseorang yang ditunjukkan dalam aktivitas, minat dan opini khususnya yang berkaitan dengan citra diri untuk merefleksikan status sosialnya.

Gaya hidup merupakan frame of reverence yang dipakai seseorang dalam bertingkah laku dengan konsekuensinya akan membentuk pola perilaku tertentu. Gaya hidup juga berkaitan dengan bagaimana ia membentuk image di mata orang lain. Selain itu gaya hidup menggambarkan keseluruhan diri seseorang yang berinteraksi dengan lingkungannya. ${ }^{38}$ Gaya hidup menurut Kotler adalah pola hidup seseorang di dunia yang diekspresikan dalam aktivitas, minat, dan opininya. Gaya hidup menggambarkan "keseluruhan diri seseorang" dalam berinteraksi dengan lingkungannya. Gaya hidup menggambarkan seluruh pola seseorang dalam beraksi dan berinteraksi di dunia. ${ }^{39}$

\footnotetext{
${ }^{35}$ Will Metzger, Tell The ..., 15

36 , Kamus Besar Bahasa Indonesia, 340

${ }^{37}$ Peter Salim, Kamus Bahasa Indonesia Kontemporer, (Jakarta: Modern English Press, 1991), 447

${ }^{38}$ sosiologibudaya.wordpress.com/2011/

${ }^{39}$ http://nitaaurell.blogspot.com/2012/01/kepribadian-dan-gaya-hidup.html
} 
Menurut kamus Antropologi gaya hidup atau life style adalah pola tingkah laku sehari-hari segolongan manusia dalam masyarakat yang dapat diamati dan yang memberi identitas khusus kepada golongan itu. ${ }^{40}$ Pengertian lain dari gaya hidup adalah suatu pola atau cara individu mengekspresikan atau mengaktualisasikan cita-cita, kebiasaan melalui cara yang unik. ${ }^{41} \mathrm{Jadi}$, dapat disimpulkan gaya hidup berarti pola perilaku seseorang atau sekelompok orang yang ditunjukkan dalam kehidupan seharihari.

\section{Gaya Hidup Pemuda Secara Umum}

Perilaku dan gaya hidup anak muda masa kini semakin maju. Hal ini dikarenakan teknologi yang semakin canggih dan tentunya dengan sarana tempat yang menunjang sehingga para anak muda dapat mengubah gaya hidupnya secara bebas dan sangat modern menurut kemauannya sendiri. Kemajuan ilmu pengetahuan dan teknologi tentunya berdampak baik maupun buruk bagi masyarakat apalagi kepada para pemuda. Dampak baiknya masyarakat bisa lebih mengenal dunia secara global dan tidak ketinggalan zaman dengan negara-negara lain. Tetapi dampak buruknya anak muda memiliki gaya hidup yang berlebihan dan selalu mengikuti perkembangan zaman sekalipun mengorbankan dirinya. ${ }^{42}$

Ada juga gaya hidup yang dimiliki oleh masyarakat secara khusus anak muda yaitu hedonisme. Gaya hidup hedonisme yaitu suatu gaya hidup yang aktivitas sehariharinya untuk mencari kesenangan hidup contohnya menghabiskan waktu untuk berbelanja, membeli barang-barang mahal, bayak bermain, clubbing, dan lain-lain. Gaya hidup ini dapat menjadi menyimpang jika apa yang dilakukannya tidak dipikirkan secara matang dan dapat membuat pemuda tersebut terjerat dalam mabuk-mabukan, seks bebas, penggunaan obat-obat terlarang, dan lain-lain. ${ }^{43}$

Jadi, gaya hidup pemuda masa kini dapat dilihat dari apa yang mereka tampilkan dalam kehidupan mereka atau aktivitasnya setiap hari, dengan siapa mereka bergaul bahkan apa yang mereka pakai atau gunakan serta apa yang dilakukan setiap hari yang telah menjadi kebiasaan. Hal ini dapat menunjukkan gaya hidup mereka dan dapat berdampak baik ataupun buruk bergantung pada gaya hidup tersebut.

\section{Hal-hal Yang Mempengaruhi Gaya Hidup}

Gaya hidup seperti yang telah dijelaskan pada bagian sebelumnya dapat didefinisikan sebagai cara hidup yang diidentifikasikan dengan bagaimana orang tersebut menghabiskan waktu mereka, apa yang mereka pikirkan tentang diri mereka. Adapun gaya hidup masyarakat pada umumnya dipengaruhi oleh dua hal yaitu faktor

\footnotetext{
${ }^{40}$ Ariyono Suyono, Kamus Antropologi, (Jakarta: Akademika Pressindo, 1985), 130

${ }^{41}$ sosiologibudaya.wordpress.com/2011/

${ }^{42}$ http://husnaenieni.blogspot.com/2013/10/gaya-hidup-masa-kini-html

43 http://contohpengertian.com/gaya-hidup
} 
internal dan faktor eksternal. Faktor internal berkaitan dengan pribadi orang tersebut antara lain:

1) Sikap seseorang

2) Pengalaman dan pengamatan terhadap kehidupan sehari-hari

3) Kepribadian seseorang

4) Konsep diri dalam menentukan hidup

5) Persepsi atau pandangan

Sedangkan faktor eksternal berasal dari luar dirinya yaitu:

1) Kelompok referensi (orang yang memberikan pengaruh baik secara langsung atau tidak langsung terhadap seseorang)

2) Keluarga

3) Kelas sosial (jabatan, harta, dan lain-lain)

4) Kebudayaan

5) Lingkungan

Dapat disimpulkan bahwa gaya hidup dapat dipengaruhi dari berbagai arah, baik internal maupun eksternal. Gaya hidup seseorang akan menentukan penilaian dari orang lain terhadap orang tersebut. Gaya hidup yang baik seperti gaya hidup mandiri atau gaya hidup sehat mungkin akan mendapat penilaian yang baik dari seseorang. Tetapi jika gaya hidupnya buruk orang akan memberikan penilaian yang buruk, bahkan tidak secara tidak langsung orang tersebut dapat dikucilkan dari masyarakat. ${ }^{44}$

\section{Gaya Hidup Pemuda Kristen}

Gaya hidup pemuda Kristen tidak boleh mengikuti gaya hidup pemuda pada umumnya apalagi bila hal tersebut bertentangan dengan Firman Tuhan. Orang Kristen ataupun pemuda Kristen mempunyai standar gaya hidup yang berdasarkan Kebenaran Firman Tuhan. Karena itu sebagai orang Kristen atau pun pemuda Kristen harus memperhatikan gaya hidupnya apakah sudah sesuai dengan Alkitab atau tidak? Gaya hidup yang bijak hanya dapat dipelajari di dalam Firman Tuhan. ${ }^{45}$ Beberapa hal yang berkaitan dengan gaya hidup pemuda Kristen antara lain:

\section{1) Berpola pikir rohani}

Setiap orang Kristen termasuk di dalamnya pemuda Kristenharus terus-menerus memusatkan pikirannya kepada Allah karena Dialah sumber segala sesuatu dan perancang segala sesuatu (Rm. 11: 36). Ada dua tanda kebenaran pola pikir tentang Allah secara rohani yaitu:

a) Adanya sukacita dalam memikirkan keberadaan Allah.

Orang yang saleh akan suka memikirkan kebaikan, kekudusan, kuasa, hikmat dan kemurahan Allah. Pemikiran semacam ini akan menyegarkan jiwa dalam keadaan

\footnotetext{
${ }^{44}$ http://contohpengertian.com/gaya-hidup

${ }^{45} \mathrm{http}: / /$ www.tabernakel.org/renungan/?id=11071801
} 
apa pun. Sebaliknya mereka yang tidak saleh hanya akan bersukacita bilamana Allah memberkati mereka. Orang percaya yang bersukacita di dalam Allah sebagaimana ia ada sekarang akan menantikan kedatangan hari itu dengan kerinduan

b) Adanya perasaan gentar dan hormat akan Allah

Hal ini dikarenakan kekudusan dan kuasa Allah yang tak terbatas dan hanya layak bagi penghormatan yang tertinggi. Mereka yang berpola pikir rohani, melalui kecintaan dan kekudusan dalam diri mereka dapat bersukacita sekaligus memuji kemuliaan dan kekudusan Allah yang tak terbatas itu.

Kecenderungan orang sebagian dari mereka mengakui keberadaan Allah, tetapi jarang memikirkannya. Kehidupan mereka tidak dipengaruhi oleh pengetahuan mereka tentang Allah. Sebagian lainnya disibukkan oleh hal-hal duniawi sehingga tidak mungkin lagi untuk berpikir tentang Allah yang seharusnya. ${ }^{46}$ Sebagai pemuda Kristen pentingnya memiliki gaya hidup rohani khususnya dalam hal pola pikir rohani. Hal ini merupakan jalan bagi orang Kristen untuk siap menanggapi segala situasi dengan cara seperti Kristus. Melalui pembaharuan jiwa orang percaya, Roh Kudus telah memulai karya-Nya untuk menjadi orang percaya serupa dengan Kristus.

\section{2) Bergaul Akrab dengan Firman Tuhan}

Dalam kehidupan Kristen tidak ada disiplin rohani yang lebih penting dari pada pemahaman Alkitab. Artinya bahwa tiada kehidupan Kristen yang sehat tanpa makanan rohani dari Firman Tuhan. Di dalam Alkitab cukup jelas, Allah berbicara kepada orang percaya tentang diri-Nya, terutama tentang Kristus. Bergaul akrab dengan Firman Tuhan berarti mendengarkan Firman Tuhan, sebagaimana dalam Roma 10:17 "Jadi iman timbul dari pendengaran, dan pendengaran oleh Firman Kristus". Membaca Alkitab dapat dilakukan secara tetap dan teratur. Hal yang perlu dilakukan oleh pemuda Kristen adalah: pertama, meluangkan waktu; kedua usahakan mempunyai daftar pembacaan Alkitab; ketiga setiap kali membaca Alkitab, mencari paling sedikit satu kata, satu istilah atau satu ayat untuk direnungkan. Setiap orang Kristen, secara khusus dalam pembahasan ini pemuda Kristen, harus memiliki kerinduan untuk bergaul karib dengan Firman Tuhan. ${ }^{47}$

Berkenaan dengan hal ini Shelton memaparkan bahwa Firman Allah terutama membantu kaum muda yaitu: 1) Memperkuat hidup dan mendorong pertumbuhan rohani, menumbuhkan perilaku yang memperluas hidup; 2) Memberikan kepada kaum muda sarana refleksi batin dalam hal pengambilan keputusan moral dan implikasinya; 3) Memberikan nilai-nilai tertentu yang menegur kaum muda agar bertobat dan bertumbuh secara penuh; 4) Mendukung perilaku yang bertanggung

\footnotetext{
${ }^{46}$ John Owen, Berpola Pikir Rohani, (Surabaya: Penerbit Momentum, 2009) 52-54

${ }^{47}$ Donald Whitney, 10 Pilar Penopang Kehidupan Kristen, (Bandung: Lembaga Literatur Baptis), 


\section{Missio Ecclesiae, 5(2), Oktober 2016, 169-189}

jawab dan mengajak kaum muda untuk menerima pertanggungjawaban atas perilakunya dalam hubungannya dengan Tuhan dan sesama. ${ }^{48}$

\section{3) Berdoa}

Allah berbicara dengan jelas kepada umat manusia melalui Roh Kudus/ Tuhan Yesus dan melalui Alkitab. Allah tidak hanya berbicara kepada orang percaya, tetapi Dia mendengarkan mereka. Dia mendengarkan setiap doa dari umat Tuhan termasuk di dalamnya doa dari para pemuda Kristen. Alkitab menyatakan bahwa orang percaya harus berdoa. Seperti yang tertulis dalam Alkitab, 1 Tesalonika 5:17, terjemahan Firman Allah Yang Hidup: "Hendaklah saudara selalu berdoa". Pengertian selalu berdoa yaitu selalu ada dalam jalur hubungan dengan Tuhan. ${ }^{49}$

Pemuda Kristen secara khusus harus selalu berdoa. Himbauan ini menyatakan secara tidak langsung bahwa alasan-alasan seperti kekurangan waktu, terlalu banyak tanggung jawab, terlalu sibuk, terlalu banyak yang dikerjakan, kurang gairah dan sebagainya tidaklah dapat dijadikan alasan untuk membenarkan keadaan rohani yang jarang berdoa. Seperti apa yang dikatakan oleh Martin Luther tentang doa: "Pekerjaan seorang penjahit ialah membuat pakaian; pekerjaan seorang tukang sepatu ialah membuat sepatu; pekerjaan seorang Kristen ialah berdoa." 50

Kehidupan rohani orang Kristen akan berjalan lebih baik bila selalu mempunyai waktu untuk menyendiri bersama Tuhan setiap hari untuk membaca Firman-Nya dan berdoa. $^{51}$. Melalui doa, Allah menunjukkan kepada orang percaya bahwa mereka adalah pemenang dalam peperangan karena doa menunjukkan kuasa berasal dari Tuhan. ${ }^{52}$ sebagai pemuda Kristen penting untuk menjadikan berdoa sebagai bagian dari gaya hidup. Hal ini bukan hanya dilakukan sewaktu-waktu tetapi menjadi bagian dari kehidupan.

\section{4) Beribadah}

Ibadah adalah bagian penting dalam kehidupan seseorang. Ibadah juga merupakan satu tuntutan bagi hidup orang percaya bahkan itu menjadi natur manusia yang adalah ciptaan Tuhan. Manusia yang diciptakan oleh Allah adalah selain sebagai makhluk jasmaniah tetapi juga rohaniah. Secara rohani ibadah adalah bagian integral dari hidup manusia. Seperti yang dikemukakan A. W. Tozer yang dikutip Manafe bahwa ibadah adalah untuk merasa dalam hati dan mengekspresikan dalam beberapa cara yang tepat dengan merendahkan diri tapi menyenangkan tentang keajaiban disertai rasa kagum dan dengan cinta yang kuat di hadapan Misteri yang paling kuno, Yang

${ }^{48}$ Charles M. Shelton, Moralitas Kaum Muda, (Yogyakarta:Penerbit Kanisius, 1988, 32

${ }^{49}$ Donald Whitney, 10 Pilar Penopang Hidup Kristen..., 72

${ }^{50}$ Ibid.

${ }^{51}$ Hope Macdonald, Belajar Berdoa, (Jakarta: BPK Gunung Mulia, 2012), 28-29

${ }^{52}$ John Piper, Jadikan Sekalian Bangsa Bersukacita, (Bandung: Lembaga Literatur Baptis, 2003), 
Mulia, yang oleh para filsuf sebut Penyebab Pertama, tapi yang kita sebut Bapa Kami Yang Ada di Surga. ${ }^{53}$

Beribadah kepada Tuhan sepanjang hidup orang Kristen menuntut adanya disiplin. Tanpa disiplin kehidupan ibadah akan menjadi lemah dan labil. Menyembah Tuhan dalam kehidupan ibadah merupakan suatu yang paling tinggi dan mulia karena menyembah Tuhan adalah memusatkan hati dan pikiran kepada Dia. A. W. Tozer mengemukakan bahwa "Kalau anda tidak mau beribadah kepada Tuhan tujuh hari dalam seminggu, maka tidak dapat dikatakan bahwa anda beribadah kepada-Nya satu hari dalam seminggu". Presiden Calvin Coolidge menyatakan: "kerohanian kita akan mulai bertumbuh hanya bila kita mulai hidup beribadah kepadaNya". ${ }^{44}$ Sebagai pemuda Kristen penting sekali memiliki kehidupan yang beribadah kepada Tuhan, baik secara pribadi maupun kelompok, hal ini juga meningkatkan pertumbuhan iman dan kerohanian setiap pribadi.

\section{5) Melayani}

Melayani Tuhan bukanlah suatu hal yang main-main. Melayani dapat mencakup pelayanan di hadapan umum seperti berkhotbah dan mengajar, tetapi dapat juga di belakang layar. Melayani dapat terlihat nyata di hadapan orang banyak seperti peranan penyanyi tunggal tetapi dapat pula tidak terlihat orang banyak seperti mengatur sound system. Selain itu melayani dapat dihargai seperti bersaksi secara memukau dalam sebuah kebaktian, tetapi dapat juga tidak menerima penghargaan seperti mencuci piring-piring kotor selesai acara ramah tamah.

Selain beberapa hal tersebut di atas, pelayanan dapat mencakup menjaga anak bayi atau mengasuh anak yang dititipkan, mengirim makanan kepada keluarga yang berkekurangan, memenuhi kebutuhan orang-orang jompo, mengantar jemput mereka yang tidak mempunyai kendaraan, mengunjungi orang sakit, dan lain-lain. Yang paling sulit adalah mempunyai hati dan sikap melayani secara khusus sebagai pemuda Kristen. Pemuda Kristen perlu mendisiplinkan diri dalam hal melayani. ${ }^{55}$

Setiap pemuda Kristen bahkan orang Kristen secara umum adalah hamba-hamba Tuhan. Dan seorang hamba Tuhan atau pelayan Tuhan melayani hanya kepada satu Tuan (kyrios) yaitu Tuhan Yesus Kristus. Seorang pelayan Tuhan harus memiliki sikap hidup yang benar termasuk sikap hidup melayani. ${ }^{56}$ Di dalam pelayanan walaupun penuh tantangan diperlukan kepatuhan kepada Tuhan, hati yang berterima kasih, yang bersukacita, yang rela mengampuni, yang rendah hati dan penuh kasih Yesus. Pelayanan sering terlihat tidak menarik dan godaan untuk berhenti melayani kadang-kadang terasa amat kuat. Karena itu seorang pelayan Tuhan harus tetap bertahan. Sekalipun tidak akan menjadi terkenal, tidak akan dipuji, kecuali dari Tuhan di dalam kekekalan.

\footnotetext{
${ }^{53}$ Ferdinan S. Manafe, Teologi Ibadah, (Batu: Literatur YPPII Batu, 2014), 3

${ }^{54}$ Donald Whitney, 10 Pilar Penopang Hidup Kristen..., 110-111

${ }^{55}$ Ibid, 137

56 , Kumpulan Makalah dan Ceramah Theologi , 109
} 
Jadi, setiap pemuda Kristen hendaknya memiliki hati yang mau melayani. Hal ini tentunya dapat tercermin dalam kehidupannya setiap hari.Mulailah dari hal-hal yang kecil, maka Tuhan akan mempercayakan hal-hal yang besar kepada setiap anak-anakNya.

\section{6) Bersaksi dan Memberitakan Injil}

Bersaksi dan memberitakan Injil adalah dua hal yang berkaitan dan seharusnya tidak terpisah. Berkenaan dengan bersaksi tentang Tuhan kepada orang lain,orang tersebut harus mengalami sungguh-sungguh kehidupan yang diubahkan Tuhan. Yesus mengubah orang berdosa menjadi orang pilihan Allah. Itulah yang disaksikan. Perubahan salib Kristus yang terjadi dalam diri seseorang harus jelas. Ini adalah titik tolaknya. Jikalau ia tidak mengalaminya, ia tidak dapat menyaksikan kepada orang lain siapakah Yesus Kristus dan apa yang telah dilakukan-Nya.

Semua orang Kristen dipanggil untuk menjadi saksi kristus dimana pun dia berada. Orang Kristen yang sudah diselamatkan, tidak boleh diam dan membiarkan orangorang di sekitarnya binasa tanpa mendapatkan kabar kesukaan tentang Yesus Kristus. Contohnya orang Kristen mula-mula (Kis. 8: 1, 4). ${ }^{57}$

Berkenaan dengan kesaksian dan pemberitaan Injil, Pondsius Takaliuang menjelaskan beberapa hal yang perlu dimengerti:

a) Lingkungan atau tempat bersaksi

(i) Di tengah kekacauan rohani (Luk.7-8 )

Pengertian kekacauan rohani yang dimaksud yaitu akan datang banyak mesias palsu. Alfred Barnes dalam bukunya melaporkan bahwa sejak pemerintahan Kaisar Adrianus pada abad kedua, ada 24 mesias palsu. Dalam majalah Times dituliskan bahwa Presiden Mobutu dari Zaire telah memproklamirkan diri sebagai mesias. ${ }^{58}$

(ii) Di tengah-tengah kekacauan politik (Luk. 21:9-10)

Dunia saat ini sedang dalam kekacauan. Di mana-mana timbul perang, huruhara, pemberontakan, dan sebagainya. Dalam keadaan seperti ini pun orang percaya harus bersaksi tentang Injil kedamaian bagi dunia yang semakin kacau ini.

(iii) Di tengah-tengah kekacauan penyakit (Luk. 21: 11)

Di banyak negara yang sedang berkembang, masalah penyakit menjadi masalah yang kompleks. Dari hari ke hari manusia semakin diliputi kecemasan. Dalam keadaan semacam inilah orang percaya perlu bersaksi kepada mereka tentang Tuhan Yesus yang berkuasa melepaskan dari penyakit; bersaksi tentang Injil kelepasan.

b) Isi Kesaksian

${ }_{58}^{57}$ D. Wellis, Metode Penginjilan, (Jakarta: Yayasan Komunikasi Bina Kasih, 1999), 115 , Kumpulan Makalah dan Ceramah Theologi, 23 
Isi kesaksian adalah mengenai Yesus yang mati untuk manusia berdosa. Yesus yang tidak berdosa, dijadikan dosa untuk manusia. Di samping itu orang percaya menyaksikan Yesus yang telah bangkit. Dia bangkit dan menang atas dosa. Orang Kristen, dalam hal ini pemuda Kristen, juga harus menyaksikan tentang Yesus yang bersedia mengampuni dosa.

c) Akibat kesaksian

Ada tiga hal yang dapat dialami orang percaya akibat kesaksian yaitu:

(i) Dianiaya oleh golongan orang beragama lain

(ii) Dianiaya oleh golongan pemerintah

(iii) Dianiaya oleh keluarga sendiri

d) Kesempatan bersaksi

Ada dua kesempatan dalam bersaksi yaitu:

(i) Di saat sedang dianiaya. Seperti halnya Paulus ditangkap, ia dapat juga bersaksi kepada Festus

(ii) Sebelum Tuhan Yesus datang kedua kali orang Kristen harus bersaksi. ${ }^{59}$

\section{BERSAKSI TENTANG KRISTUS SEBAGAI GAYA HIDUP}

Setiap orang Kristen termasuk di dalamnya pemuda Kristen diharapkan memberitakan keselamatan yang ada di dalam Yesus Kristus. Pengabaran Injil adalah mengabarkan tentang Yesus Kristus kepada orang-orang berdosa agar mereka percaya dan beriman kepada Allah melalui Yesus Kristus, menerima Yesus Kristus sebagai Tuhan dan Juruselamat dan melayani Dia yang menjadi Raja mereka di dalam persekutuan gereja-Nya. Allah tidak menjanjikan semua orang yang mendengarkan Injil akan menjadi percaya, tetapi orang Kristen dapat meyakini bahwa jikalau mereka setia dan pantang mundur dalam memberitakn Injil, dari antara mereka yang diinjili akan ada yang menjadi percaya. Selain itu hidup sebagai orang Kristen sejati juga merupakan suatu kesaksian Injili yang penuh kuasa. Kehidupan Kristen yang sejati khususnya pemuda Kristen yang menuruti Firman Allah mempunyai pengaruh. Tuhan juga memakai kehidupan orang Kristen sejati melalui tutur katanya bagaikan bau harum yang memikat orang lain sehingga orang menjadi tertarik dengan berita tentang anak-Nya.

Berikut ini contoh kesaksian Kristen yang terkuat yang diucapkan oleh seorang Kristen yang kehidupannya sesuai dengan Firman Tuhan:

Sekitar pertengahan tahun 1980, isteri saya, Caffy, membentuk kelompok pemahaman Alkitab di rumah kami untuk mendukung pertumbuhan rohani dua orang wanita yang baru menjadi Kristen. Ketika mereka datang untuk yang kedua kali, mereka membawa seorang teman yang bernama Janet. Janet mempunyai sikap yang sinis sekali terhadap hal-hal rohani, apalagi ia terlibat 


\section{Missio Ecclesiae, 5(2), Oktober 2016, 169-189}

okultisme. Namun pada malam itu Janet merasakan sesuatu yang berbeda. Berbulan-bulan kemudia baru Janet menceritakan bahwa "bau harum" kehidupan Kristen Caffy, terutama dalam kehidupan rumah tangganya yang dibarengi dengan santapan Firman Tuhan pada acara PA di rumah Caffy membuat dia ingin "mencicipi" Firman Tuhan lebih banyak lagi. ${ }^{60}$

Sebagai orang Kristen, semuanya harus bersaksi tentang apa yang telah Tuhan lakukan untuknya dan apa artinya Dia bagi orang tersebut. Mengapa orang Kristen atau pemuda Kristen tidak aktif bersaksi tentang Tuhan Yesus. Salah satu alasannya karena orang Kristen tidak cukup terlatih untuk bersaksi tentang imannya. Bahkan penyebab utama orang Kristen tidak bersaksi tentang Tuhan Yesus ialah karena tidak adanya disiplin untuk melakukannya.

Sebagian orang takut bersaksi karena mereka tidak merasa mampu menjawab segala macam pertanyaan yang akan diberikan pada mereka. Tetapi ingatlah bahwa kemampuan memberitakan Injil ataupun bersaksi tidak tergantung daripada orang yang menyampaikannya. Bukankah yang disampaikan adalah Injil-Nya. Jika Allah tidak memakai orang-orang seperti kita untuk bersaksi, maka tidak akan ada kesaksian tentang Tuhan Yesus dari manusia. Tidak ada seorang pun yang sempurna, termasuk para saksi Kristus. Semakin orang percaya kepada Tuhan Yesus, maka semakin orang percaya akan bersaksi tentang Dia dan firman-Nya. ${ }^{61}$ Pemuda Kristen hendaknya semakin menjadi seperti Kristus, maka semakin dia giat bersaksi dan memberitakan Injil Kristus, maka hal tersebut dapat menjadi gaya hidupnya.

\section{SIMPULAN}

Pada umumnya pemuda memiliki gaya hidup yang cenderung instant, mudah dipengaruhi oleh hal-hal yang ada di sekitarnya. Demikian juga dengan pemuda gereja. Keluarga maupun komunitas di mana dia berada turut mempengaruhi gaya hidupnya. Secara khusus perihal kerohanian seseorang sangat mempengaruhi gaya hidupnya. Karena itu seorang pemuda gereja atau pemuda Kristus harus memiliki gaya hidup yang berbeda dari dunia ini yaitu gaya hidup yang sesuai dengan standar Alkitab yaitu Firman Allah. Salah satunya adalah gaya hidup yang bersaksi tentang Kristus.

Berkenaan dengan hal ini pemahaman seseorang mengenai bersaksi sangat berpengaruh pada penerapan hal tersebut dalam kehidupannya. Apakah pemahamannya mengenai bersaksi bersifat sempit atau secara luas. Pada umumnya pemuda gereja memahami bersaksi dalam arti sempit yaitu menyaksikan kebaikan Tuhan, pertolongan Tuhan dalam study, keluarga, keberhasilan yang diperoleh. Lebih dari itu pemahaman

\footnotetext{
${ }^{60}$ Donald Whitney, 10 Pilar Penopang Hidup Kristen..., 137

${ }^{61}$ Ibid..., 133-135
} 


\section{Missio Ecclesiae, 5(2), Oktober 2016, 169-189}

mengenai bersaksi harus dimengerti dalam arti yang luas yakni dalam arah bersaksi tentang Kristus. Pengalaman seseorang dengan Tuhan dalam arti perjumpaan seseorang secara pribadi dengan Tuhan memulihkan kehiduapannya bahkan mendorong dia untuk menyaksikan itu bagi orang lain dengan tujuan orang lain mengalami hal yang sama. Tujuan bersaksi tentang Kristus supaya orang boleh mengenal Tuhan, percaya kepada Tuhan bahkan dapat juga menjadi saksi Kristus.

Ada tantangan ataupun hambatan yang dihadapi pada saat bersaksi tentang Kristus. Adapun hambatan yang dialami berasal dari dalam pribadi yang bersaksi maupun dari luar. Tantangan dari luar berkaitan dengan konteks masyarakat setempat, perbedaan suku, budaya dan agama yang mengarah pada perbedaan pemahaman atau konsep tentang keselamatan. Sedangkan tantangan dari dari pribadi yang bersaksi adalah adanya rasa takut, malu, tidak berani berkata-kata bahkan tidak siap untuk menghadapi resiko atau konsekuensi yang akan dialami termasuk menghadapi penganiayaan.

Berkaitan dengan hal ini diperlukan hikmat Tuhan dan pertolongan Roh Kudus dalam menyampaikan berita kesaksian tentang Kristus dan karyaNya. Secara khusus pemuda gereja yang hidup dalam konteks masyarakat Indonesia yang majemuk. Bersaksi tentang Kristus dapat dilakukan bukan hanya secara verbal tetapi juga nonverbal. Melalui perkataan dan perbuatan pemuda gereja yang berbeda dari gaya hidup dunia ini, bahkan menjadi berkat bagi banyak orang.Pengalaman hidup bersama Tuhan dan anugerah keselamatan yang dianugerahkan kepada setiap orang yang percaya kepada Kristus tidak dapat digantikan atau ditukar dengan apapun. Hal itu merupakan suatu kesukaan dan berita yang harus disampaikan kepada orang lain secara khusus orang yang belum percaya. Perbuatan Tuhan yang ajaib yang dialami orang percaya dapat diceritakan kepada orang lain sehingga orang tersebut dikuatkan iman percayanya. Tetapi dalam arti yang lebih luas berita tentang Kristus harus disampaikan kepada semua orang.

Setiap orang percaya dipanggil untuk menjadi saksi Kristus. Seorang saksi adalah seorang yang mengalami sendiri suatu peristiwa sehingga dapat menceritakan hal tersebut kepada orang lain. Demikian juga dengan seorang saksi Kristus harus memberitakan Injil tentang Yesus Kristus; memberitakan tentang kematian dan kebangkitan Tuhan Yesus Kristus, dan barangsiapa yang percaya kepada-Nya mendapat pengampunan dosa dan memperoleh hidup yang kekal.

Demikian juga dengan para pemuda dipanggil untuk menjadi saksi Kristus yaitu bersaksi tentang Kristus melalui kehidupan para pemuda dan menjadikan itu sebagai gaya hidup setiap hari. Gaya hidup berarti pola perilaku yang sudah menjadi kebiasaan dalam kehidupan seseorang, dan hal ini sudah menjadi bagian dalam hidupnya. Para rasul dalam kitab Kisah Para Rasul menjadikan bersaksi tentang Kristus sebagai gaya hidup mereka. Walaupun mengalami tantangan ataupun penganiayaan, para rasul tetap mentaati perintah Tuhan Yesus untuk bersaksi (Kis. 1: 8).Bersaksi bukan hanya sekedar berkata-kata tentang pertolongan Tuhan, tetapi menyampaikan tentang berita kesaksian yaitu Injil Yesus Kristus, bahkan hidup sesuai dengan teladan Kristus. Pentingnya bagi orang percaya untuk menyatakan kesaksiannya melalui perkataan dan perbuatan 
sehingga orang yang belum percaya dapat mengenal Kristus melalui kehidupan orang percaya.

Gereja perlu terus mendorong para pemuda untuk menggunakan dan memaksimalkan semua potensi yang ada pada mereka dalam arah yang benar yaitu terus dipakai untuk melayani Tuhan. Bahkan gereja perlu juga mendorong semua pemuda untuk terlibat dalam pelayanan gereja melalui program-program pelayanan yang dibuat oleh gereja. Tentunya masing-masing pemuda dilibatkan dalam bidangnya sesuai dengan apa yang dapat dikerjakannya.

Bagi pemuda gereja, perlunya dibuat kelompok-kelompok kecil atau kelompok tumbuh bersama bagi para pemuda, sehingga dari situ para pemuda semakin bertumbuh di dalam Tuhan. Tentunya hal berdampak pada kerohanian yang semakin dewasa bukan hanya pada satu pribadi tetapi kepada semua pemuda. Selain itu pokok-pokok pengajaran tentang bersaksi dapat diajarkan kepada para pemuda. Mulai dari sikap pribadi yang bersaksi, landasan dari bersaksi tentang Kristus, bagaimana cara bersaksi, tujuan dari bersaksi dan gaya hidup seorang yang menjadi saksi Kristus. Dengan demikian hal ini dapat mendorong pemuda gereja untuk semakin giat bersaksi tentang Kristus dan menjadikannya sebagai gaya hidup.

\section{DAFTAR PUSTAKA}

Douglas, J.D,

1995 Ensiklopedi Alkitab Masa Kini, Jilid 2 M-Z. Jakarta: Yayasan Bina Kasih/OMF)

M. Echols, M. John,

2003 Kamus Inggris-Indonesia. Jakarta: PT Gramedia Pustaka Utama

Ellis, D.W

1999 Metode Penginjilan, (Jakarta: Yayasan Komunikasi Bina Kasih/OMF)

Guthrie, Donald

1991 Teologi Perjanjian Baru I, (Jakarta: BPK Gunung Mulia)

Halim, Makmur, 2003 Model-model Penginjilan Yesus, (Malang: Penerbit Gandum Mas)

Hornby, dkk,

1984 Kamus Inggris Indonesia, (Jakarta: PT Pustaka Ilmu)

Lumintang, Stevri

2006 Misiologi Kontemporer, (Batu: Departemen Literatur PPII)

Lexy, J. Moleong,

2012 Metode Penelitian KualitatifEdisi revisi, (Bandung: PT Remaja 
Rosdakarya)

Hope Macdonald,

2012 Belajar Berdoa, (Jakarta: BPK Gunung Mulia)

Mcelrath, W.N - Mathias, Billy, 1986 Ensiklopedia Alkitab Praktis, (Bandung: Lembaga Literatur Baptis)

Metzger, Will, 2005 Beritakan Kebenaran, (Surabaya: Penerbit Momentum)

Morris, Leon 1996 Teologi Perjanjian Baru, (Malang: Penerbit Gandum Mas)

Manafe, Ferdinan S. 2014 Teologi Ibadah, (Batu: Literatur YPPII Batu)

Napel, Henk Ten, 1989 Kamus Teologia Inggris-Indonesia, (Jakarta: BPK Gunung Mulia)

Owen, John 2009 Berpola Pikir Rohani, (Surabaya: Penerbit Momentum)

Park, Yune Sune, 2001 Tafsiran Alkitab Kisah Para Rasul, (Batu: Departemen Literatur YPPII)

Piper, John 2003 Jadikan Sekalian Bangsa Bersukacita, (Bandung: Lembaga Literatur Baptis)

Richards, Lawrence O, 1985 Expository Dictionary of Bible Words, (Grand Rapids Michigan: The Zondervan Corporation)

Rosalind Rinker, 1991 Bersaksi dengan Tenang Hati, (Surabaya: YAKIN)

Salim, Peter 1991 Kamus Bahasa Indonesia Kontemporer, (Jakarta: Modern English Press) 
Shelton, Charles M.

1988 Moralitas Kaum Muda, (Yogyakarta:Penerbit Kanisius)

Suyono, Ariyono,

1985 Kamus Antropologi, (Jakarta: Akademika Pressindo)

Swindoll, Charles R.

1982 Mantapkan Keyakinanan Anda, (Surabaya: YAKIN, 1982), 186

Tong, Stephen,

2007 Kerajaan Allah, Gereja dan Pelayanannya, (Surabaya: Penerbit Momentum)

Verwer, George

2001 Melangkah Keluar dari Kenyamanan Dunia, (Jakarta: Yayasan Obor Mitra)

Wellis, D

1999 Metode Penginjilan, (Jakarta: Yayasan Komunikasi Bina Kasih)

Whitney, Donald

199210 Pilar Penopang Kehidupan Kristen, (Bandung: Lembaga

Literatur Baptis)

Wiersbe, Warren W,

2002 Dinamis di dalam Kristus, (Bandung: Yayasan Kalam Hidup)

Zodhiates, Spiros

1993 The Complete Word Study Dictionary, (Chattanooga: A.M.G Publishers)

1990 Kumpulan Makalah dan Ceramah Teologi, (Batu : Dian - Majalah Institut Injil Indonesia)

sosiologibudaya.wordpress.com/2011/

http://nitaaurell.blogspot.com/2012/01/kepribadian-dan-gaya-hidup.html

http://husnaenieni.blogspot.com/2013/10/gaya-hidup-masa-kini-html

http://contohpengertian.com/gaya-hidup

http://www.tabernakel.org/renungan/?id=11071801 